Marcin Böhm*

\title{
Kildare rebellion (1534-1535) in the Annals of the Four Masters
}

https://DOI: 10.1515/openms-2020-0103

Received Jun 28, 2020; accepted Aug 27, 2020

\begin{abstract}
One of the most important Irish historical sources, which are the Annals of the Four Masters, written in the modern period, provide us with unusually valuable information about the history of the Emerald Island. In addition to data from the ancient or medieval periods, it also contains material from the difficult 16th and 17th centuries for Ireland, when it came under the yoke of English Protestants, who were initially represented by the Tudors and then by the Stuart dynasty. The Annals of the Four Masters also witnesses the resistance of the Irish, both those from Hiberno Normans and Gaelic Irish, to the demands of new authorities, including the rejection of Catholicism and total submission to the power of the kings of England. One such attempt, although unsuccessful, was the Kildare rebellion undertaken by Silken Thomas Earl of Kildare in the late 1630s. The laconic nature of Annales' accounts, as well as the omission by this source of many important data, makes it an auxiliary material related to military history in the case of the Kildare rebellion. This is interesting because, in the context of later revolts that broke out in Ireland against the authority of the Tudors or Stuarts, in the era of further conquest of the island, this source is very valuable research material in this field.
\end{abstract}

Keywords: Kildare rebellion, Silken Thomas, Annals of the Four Masters, Ireland in XVI Century, Henry VIII

\section{Introduction}

At the beginning of the 16th century, Ireland was an area where the interests of Tudors, the families of HibernoNormans, and the descendants of former Gaelic Irish kings clashed. This situation resulted from the fact that the new English dynasty independently controlled the area around Dublin called Pale, while in the remaining Irish lands it was condemned to cooperate with the local nobility, primarily descendants of the former conquerors of this island from the 12th century, the Normans. After the departure of Henry VIII (1509-1547) from the Roman church and the creation of the Church of England, this became extremely difficult, due to Catholicism, to which Hiberno - Normans remained mostly faithful. One such Irish family slowly drifting towards open rebellion were the Earls of Kildare, descended from the famous FitzGerald family. It was the representatives of this family who were responsible for one of the attempts of resistance to Tudor rule, which is called by the historians the Kildare rebellion. His name was Thomas FitzGerald, 10th Earl of Kildare (1513-1537), who was later nicknamed Silken because at the beginning of his rebellion, he was accompanied by a group of Irish mercenaries-gallowglasses with silk fringes attached to their helmets ${ }^{1}$.The main purpose of this article is to present this rebellion in one of Ireland's most important historical sources, the Annals of the Four Masters, from the point of view of military

1 Marquis of Kildare (Charles William FitzGerald, 4th Duke of Leinster), The Earls of Kildare and their ancestors from 1057 to 1773, Dublin 1858, p. 131.

*Corresponding author: Marcin Böhm. The author is a professor of history whose specialization, apart from the history of Byzantium, is the military of the Normans (also in Ireland) in the Middle Ages. He can be contacted at mabohm@wp.pl. ORCID: http://orcid.org/0000-0002-5393-3176

๖ Open Access. () 2020 Marcin Böhm, published by De Gruyter. (G) Br Attribution 4.0 Public License. 
history. This is an unusual source written in the modern era in Ireland and covers information from Biblical times up to 1616 A.D. It was written near Donegal Abbey between 1632 and 1637. The authors of this work were the monks Mícheál Ó Cléirigh, Cú Choigcríche Ó Cléirigh, Fearfeas Ó Maol Chonaire and Cú Choigríche Ó Duibhgeannáin². Annals were written in Irish, and their first part-translation to English in the nineteenth century was made by Owen Connellan, and a full translation was prepared decade later, by another historian John O'Donovan ${ }^{3}$. It is obvious that the Annals present events related to Ireland from the point of view of the Irish themselves, apart from some aspects of their relationship with the English crown, or Thomas Cromwell's participation in Henry VII's policy towards Green Island ${ }^{4}$. The scientific edition of this source combined with the translation made by John O’Donovan will be the basis of our considerations contained in this article.

\section{Source analysis}

The Annals account of the future rebellion begins with a description of the events of 1534, which is worth quoting in full here, namely:

Great complaints and accusations were transmitted from the chiefs of the English of Ireland and the Council to the King, Henry VIII., of England, against the Lord Justice (i.e. the Earl of Kildare, Garrett Oge, the son of Garrett, son of Thomas, commander of the strength and power of Ireland); and the Earl went over to the King, to vindicate his conduct before him, but it was of no avail, for he was taken and confined in the tower, where he remained for one year, and they were exerting the rigors of the law against him. Earl Garrett, on his departure for England, left the sword of the King with his son, Thomas. Others, however, say that it was William Skeffington who succeeded Garrett in the office of Lord Justice. ${ }^{5}$

This passage cited above presents us in some detail the situation of the FitzGerald family of Kildare in the early 1630s. The father of Thomas - Gerald FitzGerald, 9th Earl of Kildare (1487-1534), twice married the cousins of the first Tudors on the English throne, Henry VII (1485-1509) and his son Henry VIII ${ }^{6}$. Both marriages allowed him to become a man from the Tudor clan, who pursued their interests in Ireland, in various positions assigned to him by both these rulers. In 1505 he was appointed as Lord High Treasurer of Ireland? ${ }^{7}$ He was during his life three times chosen as a Lord Deputy of Ireland. Great ambition and the Earl's policy in Ireland quickly brought his enemies. One of them was Piers Butler, 8th Earl of Ormond, 1st Earl of Ossory (1467-1539), husband of his sister Margaret ${ }^{8}$. Gerald was similarly in

2 For authorship of the Annals, see Cunningham, Bernadette, 2010. The Annals of the Four Masters: Irish History, Kingship, and Society in the Early Seventeenth Century, Dublin; Lizeray, Henri, 1882. Le livre des quatre maîtres: Annales du royaume d'Irlande, depuis les origines jusqu'à l'arrivée de saint Patrice, Leroux; Mc Carthy, Daniel, 2008. The Irish Annals: Their Genesis, Evolution and History, Dublin; Ó Muraíle, Nollaig, 1987. “The autograph manuscripts of the Annals of the Four Masters”, Celtica, vol. 19, pp. 75-95; O’Sullivan, William, 1999. “The Slane manuscript of the Annals of the Four Masters”, Ríocht na Mídhe: Journal of the County Meath Historical Society, vol. 10, pp. 78-85.

3 Connellan, Owen, 1846, The Annals of Ireland, translated from the original Irish of the Four Masters, Dublin. O'Donovan, John, ed., 1856, Annala rioghachta Eireann: Annals of the Kingdom of Ireland, by the Four Masters, from the earliest period to the year 1616 (in Irish and English), Volume 5 (AD 1501-1588), Royal Irish Academy; Concannon, Helena, 1948. John O’Donovan and “The Annals of the Four Masters", Studies: An Irish Quarterly Review Vol. 37, No. 147, pp. 300-307.

4 Ellis Steven G., 1980. „Thomas Cromwell and Ireland, 1532-1540”, The Historical Journal, Vol. 23, No. 3, pp. 497-519; Brady, Ciaran, 2002. The Chief Governors: The Rise and Fall of Reform Government in Tudor Ireland 1536-1588, Cambridge, p. 2; Bradshaw, B., 1977. 'Cromwellian reform and the origins of the Kildare rebellion', Transactions of the Royal Historical Society, 5th series, 27, pp. 69-93.

5 Eccnach, \& iomchosaoíd mór do dhol ó maithibh Gall \& ón comairle ar an iustis (iarla Cille Dara Geroitt Ócc mac Geróitt, mic Tomais forlamhaidh neirt \& cumhachta Ereann) gusan rígh an t-ochtmhadh Enri go Saxaibh, \& an t-iarla do dhol do shaighidh an rígh do ghabhail a leithscéil fris, \& nír bo tarbha dó ar ro gabhadh é, \& ro cuireadh isin Tor, \& baoí ann fri h-edh m-bliadhna, \& ro bás acc imirt dligidh fair. Ro fháccaibh an t-iarla Geróitt cloidhimh an righ aga mac Tomas ag dol dó go Saxaibh. At-berat aroile gur bó h-e Uilliam Scceimonton baoí ina iustis i n-ionadh Ghearóitt.O'Donovan, John, ed., 1856, Annala rioghachta Eireann: Annals of the Kingdom of Ireland, Volume 5 (AD 1501-1588), pp. 1418-1419; Marquis of Kildare, The Earls of Kildare, p. 117; Bradshaw, B., 1977. 'Cromwellian reform', p. 78.

6 Marquis of Kildare, The Earls of Kildare, p. 80 and 83.

7 Marquis of Kildare, The Earls of Kildare, p. 80.

8 Marquis of Kildare, The Earls of Kildare, p. 94; Ellis Steven G., 1976-77, 'Tudor policy and the Kildare ascendancy in the lordship of Ireland', Irish Historical Studies 20 (1976-7), pp. 240-241; Quinn, David B., 1961., „Henry VIII and Ireland, 1509-34”, Irish Historical Studies, Vol. 12, No. 48, pp. 322. 
conflict with the Earl of Desmond and with the O'Neill and O'Donnell families'. The tension caused by his policy in Ireland caused him to be called to England in 1525 and he was in captivity for four years in the Tower fortress ${ }^{10}$. He returned from England because he finally managed to buy his way out of prison, but was also accompanied by a newcomer - Sir William Skeffington (1465 - 1535, an English noble) who served as a new Lord Deputy of Ireland ${ }^{11}$. Reconciliation with the king and his men was short because the ambitious Gerald once again returned to offensive action against Earl of Ormond and Butler family, and their allies, as well as against the Archbishop of Dublin, John Allen (1476-1534) ${ }^{12}$. He was also later accused of trying to ally with Irish lords not recognizing the Tudors rule. Gerald also had to buy weapons from the continent for his people ${ }^{13}$. He was also accused of traveling to Scotland in winter 1533-1534 in search of an ally against Henry VIII ${ }^{14}$. These deeds resulted in the Earl of Kildare's call to England which the Annals cited above present. The Annals do not mention, however, that Henry VIII, concerned about the situation in Ireland, as well as implementing of his religious reforms and also his divorce, encouraged Gerald to come to his court, allowing him to transfer his power and competence during the council in Drogheda in February 1534 (which he had in Pale and Meath) to his son Thomas, in this time holding the title of Lord Offaly ${ }^{15}$.

In England, the father of Thomas arrived at the Tower, which was understandable because he was connected with the royal family, where, according to the source, he was to spend a year. At the time of his departure to meet the king, he left his sword and succession to his son Thomas, which the authors of Annals show us. They say nothing about the fact that Gerald, having heard that he would be dismissed from his functions, because of his inability to control chaos in Ireland and Pale, began to transfer supplies from royal outposts under his control to his castles ${ }^{16}$. Also, they don't mention that Gerald in the Tower was in contact with his son Thomas, Lord Offaly, a future rebe ${ }^{17}$. Therefore, his death or possible illness could not be any surprise to his son, since the correspondence between them existed. Concerning the death of Gerald, the authors of Annals left the following information under the Year 1535:

The Earl of Kildare, Lord Justice of Ireland (Garrett Oge), the son of Garrett, son of Thomas, the most illustrious of the English and Irish of Ireland in his time, for not only had his name and renown spread through all Ireland, but his fame and exalted character were heard of in distant countries of foreign nations, died in captivity in London. ${ }^{18}$

At this point, the authors of the source somewhat destroy the actual chronology of events. Gerald dies in December of 1534, so it was when the uprising caused by his son spreads well across the lands belonging to the English crown in Ireland ${ }^{19}$. Just after the account of the death of the 9th Earl of Kildare, we immediately have in the Annals a description of his son's rebellion against the Tudors:

9 Ellis Steven G., 1976-77, ‘Tudor policy”, pp. 249.

10 Ellis Steven G., 1976-77, ‘Tudor policy”, pp. 246.

11 Marquis of Kildare, The Earls of Kildare, p. 108; Ellis Steven G., 1976-77, “Tudor policy”, pp. 243-244; Ellis Steven G., 1980. „Thomas Cromwell and Ireland pp.499; Ó. Siochrú, Micheál, 1996. „Foreign Involvement in the Revolt of Silken Thomas, 15345”, Proceedings of the Royal Irish Academy. Section C: Archaeology, Celtic Studies, History, Linguistics, Literature, Vol. 96C, No. 2, p. 50; Quinn, David B., 1961., „Henry VII”, p. 337; Cunningham, Bernadette; Gillespie, Raymond, 1990. „Englishmen in sixteenth-century Irish Annals”, Irish Economic and Social History, Vol. 17, p. 10.

12 Ellis Steven G., 1976-77, 'Tudor policy”, pp. 249, 252.

13 Ó. Siochrú, Micheál, 1996. „Foreign Involvement”, p. 50.

14 Ó. Siochrú, Micheál, 1996. „Foreign Involvement”, p. 51.

15 Marquis of Kildare, The Earls of Kildare, p. 113-115; Ó. Siochrú, Micheál, 1996. „Foreign Involvement”, p. 51.

16 Ellis Steven G., 1976-77, 'Tudor policy”, p. 254.

17 Ellis Steven G., 1976-77, ‘Tudor policy”, p. 259-260; Bradshaw, B., 1977. ‘Cromwellian reform”, p.90.

18 Iarla Cille Dara (.i. iustis na h-Ereann) Geróitt Ócc mac Geróitt mic Tomais dearscaightheach Gall \& Gaoidheal Ereann ina aimsir, uair ní namá leth a ainm \& a erdearcus fo Erinn uile acht ro clos h-i criochaibh eitirchianaibh eachtair-cheneóil a alladh, \& a ard-nós, do écc ina braighdenus h-i Lonndain. O’Donovan, John, ed., 1856, Annala rioghachta Eireann: Annals of the Kingdom of Ireland, Volume 5 (AD 1501-1588), pp. 1418-1419; Ellis Steven G., 1976-77, 'Tudor policy”, pp. 257; Maxwell, Constantia, 1979. The Rebellion of “Silken Thomas” (1534-5), Dublin Historical Record Vol. 32, No. 2, p. 68 (1 page).

19 Marquis of Kildare, The Earls of Kildare, p. 118; Ó. Siochrú, Micheál, 1996. „Foreign Involvement”, p. 56. 
After which his son, Thomas, proceeded to avenge his father upon the English and all who had been instrumental in removing him from Ireland. He resigned the King's sword and did many injuries to the English. The Archbishop of Dublin came by his death through him, for he had been opposed to his father: many others were slain along with him. He took Dublin from Newgate outwards, and pledges and hostages were given him by the rest of the town through fear of him. The son of the Earl on this occasion plundered and devastated Fingall from Slieve Roe to Drogheda, and made all Meath as it were tremble beneath his feet. ${ }^{20}$

The above description is an extremely laconic way that presents the course of the outbreak of the uprising. Firstly the authors of Annals postpone the outbreak of rebellion to 1535, while it happened in 1534. We know that Thomas rejected the authority of King Henry VII and did harm to the English to avenge his father. The assassination of the Archbishop of Dublin, along with many other newcomers from England, was one of the stages of this rebellion, because the aggression of the new Earl of Kildare was directed against them ${ }^{21}$. The authors speak equally sparingly about clashes near Dublin, mentioning only the occupation of a part of the city and hostages taken from other residents of that town. Besides, there is a reference to the military activities of the young earl in Pale and Meath, which were to end according to Annals, with his success. There is no information in the Annals account of the place where Silken Thomas's rebellion began, his nickname, nor of his companions, or the lack of his decisive military successes. When the rebellion began at the beginning of June 1534, despite having several fortresses in Pale in his hands and stocks seized from the king, he failed to capture the Dublin castle, which remained loyal to Henry. Also, the confiscation of the property of the king and his supporters did not contribute to his popularity, as did the proposals he made to the Butler family. There is also no mention of the clashes that Thomas had to fight with the latter, in particular with Piers Butler in August and September, who did not pass to his side ${ }^{22}$. There is also no mention of the incompatible issues of Silken Thomas and his supporters on church reforms, which Henry VIII also introduced in Ireland, or about the attempt to talk to the Pope, or Charles V (1519-1556), Holy Roman Emperor, which the young earl undertoo $\mathrm{k}^{23}$. Thomas even promised the emperor that the Irish would rise against the English if they received the support of 12,000 Spaniards ${ }^{24}$.

The actions of the young Earl, which forced many Englishmen to flee from Ireland, were met with a definite response from Henry VII, as the Annals also inform us:

When the King had received intelligence of this he sent relief to the English, namely, William Skeffington, as Lord Justice, and Leonard Gray, with a great fleet, and these proceeded to plunder all (the territory) that

20 Ro gabh iaramh mac an iarla .i. Tomas ag díoghail a athar ar Ghallaibh, \& ar gach n-aén tucc fochann dia chor a h-Eirinn, \& ro ath-chuir cloidhemh an rígh uadha, \& do-ghni uilc iomdha fri Gallaibh, \& fo-gheibh aird-espoc Atha Cliath a oidheadh lais, ar baoi-sidhe i n-acchaidh a athar \& ro marbhadh beos daoine ele amaille fris. Do-gabhadh lais Baile Atha Cliath on n-Geta Nua amach, \& do-radadh geill \& braighde dhó ar a ómhan ón c-cuitt ele don bhaile. Ro léir-airccedh, \& ro láin-mhilleadh Fine Ghall ó Shliabh Ruadh go Droichet Atha gur bhó fód crithigh an Mhidhe uile la mac an iarla don cur-sin. O’Donovan, John, ed., 1856, Annala rioghachta Eireann: Annals of the Kingdom of reland, Volume 5 (AD 1501-1588), pp. 1418-1421; Marquis of Kildare, The Earls of Kildare, p. 117-118; R. Edwards, Dudley, 1934, „Venerable John Travers and the Rebellion of Silken Thomas”, Studies: An Irish Quarterly Review Vol. 23, No. 92, pp. 689; Maxwell, Constantia, 1979. The Rebellion of "Silken Thomas", p. 68; A New History of Ireland, Vol. 3: Early Modern Ireland, 1534-1691, ed. T.W. Moody, F.X. Martin, Oxford 1991, p. 38-39; Hamilton, Hans Claude, ed., 1860. Calendar of the State Papers relating to Ireland of the reign Henry VIII., Edward VI., Mary and Elisabeth, London, p. 10.

21 Marquis of Kildare, The Earls of Kildare, p. 134-135; Ellis Steven G., 1976-77, 'Tudor policy”, p. 260; Ellis Steven G., 1980. „Thomas Cromwell and Ireland, pp.505; Hiberno-Normans from the fourteenth century became increasingly tied to their new homeland Ireland, treating newcomers from England and Wales, despite often even kinship as foreign. Lydon, James, 1995. „Ireland and the English Crown, 1171-1541”, Irish Historical Studies, Vol. 29, No. 115, pp. 292-293

22 Marquis of Kildare, The Earls of Kildare, p. 136-138; Ellis Steven G., 1976-77, ‘Tudor policy”, p. 260; Brady, Ciaran, 2002. The Chief Governors, p.3; Hamilton, Hans Claude, ed., 1860. Calendar of the State, p. 10.

23 Murray, James, 2008. Enforcing the English Reformation in Ireland: Clerical Resistance and Political Conflict in the Diocese of Dublin, 1534-1590, Cambridge, pp. 82-83; Ellis Steven G., 1976-77, ‘Tudor policy”, p. 265; Ó. Siochrú, Micheál, 1996. „Foreign Involvement”, p. 53-54; McCormack, Anthony M., 1997. „Internecine Warfare and the Decline of the House of Desmond, c. 1510 - c. 1541", Irish Historical Studies, Vol. 30, No. 120, p. 501.

24 Marquis of Kildare, The Earls of Kildare, p. 143; Ó. Siochrú, Micheál, 1996. „Foreign Involvement”, p. 56. 
was under the jurisdiction of the Earl's son. They afterward took Magh Nuadhat, Thomas's town, and expelled himself from his territory. ${ }^{25}$

Skeffington brought with him 2,300 soldiers who were instrumental in maintaining Pale for English, as well as for the offensive against Thomas FitzGerald ${ }^{26}$. The latter tried to avoid open clashes and focused on defending his castles in Kildare. His supporters' ranks began to melt, especially after the English had taken Maynooth Castle, where it was captured by treason, and then its crew was murdered at the request of Skeffington ${ }^{27}$. The decisive actions of the English, which are again not very detailed in the information contained in the Annals, contributed to split and betrayal in FitzGerald family:

His father's five brothers also rose against Thomas, to assist the English, namely, James Meirgeach, Oliver, John, Walter, and Richard, for they thought that if Thomas were conquered one of themselves might obtain the earldom. When the aforesaid Englishmen were not able to make a prisoner of Thomas (after having taken his manors and towns from him, and driven him for asylum to the Irish of the south of Ireland, especially to the O'Briens and O'Conor Faly, who all were a firm and powerful bulwark against them, and at war with them) they resolved in council to proffer him a pretended peace, and take him by treachery; whereupon they sent Lord Leonard to the Earl's son, who promised pardon on behalf of the king, so that he coaxed him with him to England, where he was immediately seized and placed in the King's tower, in bondage and captivity. Lord Leonard returned to Ireland; and the Lord Justice of Ireland William Skeffington, having died, he assumed his place, and he took to him the sons of Garrett, the son of Thomas, the Great Earl of Kildare, namely, James Meirgeach, Oliver, John, Walter, and Richard, and they were for some time in his company and friendship. They were however finally seized on, they being under his protection, and sent to the King of England; and they were immediately clapped into the King's tower, in which was also the heir to the earldom, i.e. Thomas; and there were they all six! 28

The Annals account is the most detailed here. We learn from that source about participating in a rebellion against Henry VIII, Thomas's other closest relatives, and later that this FitzGerald was betrayed by his uncles who no longer wanted to continue the fight with the English. The young earl, whose rights to the title of Earl of Kildare, Henry VIII never confirmed, headed for the lands of southern Ireland, belonging to the supporting him O'Briens and O'Connor clans, which resisted fierce both the English and HibernoNormans cooperating with them ${ }^{29}$. The Annals give information about the death of Skeffington and the takeover of his function by Leonard Gray, brother-in-law of Gerald FitzGerald. Gray, taking advantage of

25 Iarná fhios-sin don rígh do chuir fóiridhin go Gallaibh i. Uilliam Scemonton ina iustis, \& Linard Grai go c-cobhlach mór amaille friu \& ro gabsatt-sidhe acc milleadh a m-baoí fó mhamus mic an iarla. Gabhthar leó iarttain baile Tomais .i. Magh Nuadhat \& ro ionnarbsatt Tomas asan tír. O’Donovan, John, ed., 1856, Annala rioghachta Eireann: Annals of the Kingdom of reland, Volume 5 (AD 1501-1588), pp. 1420-1421.

26 Ellis Steven G., 1976-77, ‘Tudor policy”, p. 268; Ó. Siochrú, Micheál, 1996. „Foreign Involvement”, p. 56; Hamilton, Hans Claude, ed., 1860. Calendar of the State, p. 11.

27 Marquis of Kildare, The Earls of Kildare, p. 148; Ellis Steven G., 1980. „Thomas Cromwell and Ireland, pp.516-517; Ellis, Steven G., 1981. „Henry VIII, rebellion and the rule of law”, The Historical Journal, 24, 518; A New History of Ireland, III, p. 39; Hamilton, Hans Claude, ed., 1860. Calendar of the State, p.12.

28 Eirgitt beós coiccear dearbrathar a athar i n-aghaidh Tomais do congnamh lá Gallaibh (Semus Merccech, Oiliuér, Sean, Uater, \& Risderd) ar bá dóigh leó gomadh la h-aon aca an iarlacht dia c-cloíti inní Tomas. An tan na caomhnactar na Saxain rémhráite Tomas do ergabhail iar m-buain a bailtedh \& a mhainer de, \& iarná athcur i n-ucht Gaoidhel Dheiscirt Ereann, \& go sonnradhach Síol m-Briain, \& Ó Conchobhair Failge, \& iat-séin uile ina c-cleith chobsaidh comhnairt ina n-acchaidh ag coccadh friú bá h-é ní do sccrúdsat ina n-airle brécc-sídh do tairccsin dó, \& cealcc do dhénamh chuicce go ro fhaoídhset Lord Linard h-i c-cenn mic an iarla, \& ro thingheall-sidhe pardún dó a h-ucht an rígh go ro bhrécc lais go Saxaibh é. Gabthar mac an iarla fo chédoir, \& cuirther h-i t-Tor an righ é i m-braighdenus \& chimidheacht. Tanaic Lord Linard i n-Erinn tar a ais doridhisi, \& ro écc an iustis baoi i n-Erinn .i. Uilliam Scemonton, \& geibhidh-sium ionadh an iustis cuicce \& tucc dia shaicchidh clann iarla mhóir Cille Dara .i. clann Geróitt mic Tomais, Semus Meirgech, Oileuér, Sean Uátér, \& Risdeard \& battar ina caoimhtheacht, \& ina muintearas do gres. Ro gabhadh lais iatt fó dheóidh iar m-beith dóibh for a ionchaibh, \& do chuir do shaighidh righ Saxan iad. Ro cuiritt-sidhe fó cédóir h-i t-tor an rígh airm i m-baoi oidhre na h-iarlachta .i. Tomas go m-battar ann ina seisear. O’Donovan, John, ed., 1856, Annala rioghachta Eireann: Annals of the Kingdom of reland, Volume 5 (AD 1501-1588), pp. 1420-1423; Ellis, Steven G., 1981. „Henry VIII, rebellion”, p. 523-524; Hamilton, Hans Claude, ed., 1860. Calendar of the State, p. 13 and 16.

29 Marquis of Kildare, The Earls of Kildare, p. 150. 
the weakening position of Thomas FitzGerald's, offered him peace talks, which resulted in the rebel being taken to England and locked up in the Tower. This event took place in August $1535^{30}$. The author of this fragment of the Annals ends his entry related to the fall of Kildare with the news of the capture of Thomas's uncles, who were also taken by Leonard Gray to England and also placed in the Tower, where they joined their relative.

The thread related to the rebellion of the FitzGeralds of Kildare is closed by the creators of Annals in an entry from 1537, where the following is written:

Thomas, the son of the Earl of Kildare, the best man of the English of Ireland in his time, and his father's five brothers, whom we have already mentioned, namely, James Meirgeach, Oliver, John, Walter, and Richard, were put to death in England on the 3rd of the Nones of February; and all the Geraldines of Leinster were exiled and banished. The earldom of Kildare was vested in the King; and every one of the family who was apprehended, whether lay or ecclesiastical, was tortured and put to death. These were great losses and the cause of lamentation throughout Ireland..$^{31}$

The above-cited data from the source shows us the end of the greater part of the FitzGerald family from Leinster. None of them was pardoned and all were killed 3 February $1537^{32}$. Their land was taken over by the crown. To some extent, the killing of these men was supposed to be a show of strength on the part of Henry VIII, who, holding them captive for almost two years, finally decided to act in such a cruel way, which caused a shock among both Hiberno-Norman nobility and Celtic chiefs ${ }^{33}$. In total, 75 executions were carried out after the rebellion ${ }^{34}$.

\section{Results of the Silken Thomas rebellion}

The main results of the Silken Thomas rebellion were:

1. Creation of a permanent garrison in Dublin, which was staffed with royal men (initially 200, then even 500 soldiers). This condition remained until 1542.35

2. The murder of some of the Fitzgeralds by Henry VIII pacified the remaining Irish magnate families who lost their desire to revolt against royal power. ${ }^{36}$

3. Finally, Henry VIII declared himself King of Ireland in 1542.

Why, then, is our source, which was analyzed in this article, so silent about the most important military events of that rebellion? Remember that the Annals were written in the seventeenth century about 100 years after Thomas the Earl of Kildare rebellion. Their main sponsor of that source was Fearghal Ó Gadhra (1597 - 1660), who was lord of Coolavin, a location in north Connacht. The work itself was also written in the north-west of Ireland, in County Donegal, and thus far from Dublin and the eastern part of the island subordinate to the

30 Marquis of Kildare, The Earls of Kildare, p. 153-154; Ellis Steven G., 1976-77, 'Tudor policy”, p. 268; Ellis Steven G., 1980. „Thomas Cromwell and Ireland, pp. 506; A New History of Ireland, III, p. 41; Guy, John, 2000. The Tudors: A very short introduction, Oxford, p. 38; Hamilton, Hans Claude, ed., 1860. Calendar of the State, p. 14.

31 Tomas mac iarla Cille Dara mac as ferr tainicc ina aimsir do Ghallaibh Ereann, \& cuiccer derbhrathar a athar amhail remhebertmar (.i. Semus Meirccech, Oiliuer, Sean, Uatér, \& Risdeard) do chor chum báis h-i Saxaibh .3. Nonas Februarii, \& Geraltaigh Laighen uile d'athchur \& d'ionnarbadh. Iarlacht Cille Dara do thóccbháil dochum an righ \& gach duine ar a ruccadh do clereach no do thuata dá muintir do chur cum báis \& bioth-oidheda. Ba h-adhbhal na h-échta \& na h-esbadha ar fhud Ereann iadsén an tan-sin. O’Donovan, John, ed., 1856, Annala rioghachta Eireann: Annals of the Kingdom of reland, Volume 5 (AD 15011588), pp. 1442-1445.

32 McCormack, Anthony M., 1997. „Internecine Warfare”. p. 506.

33 Marquis of Kildare, The Earls of Kildare, p. 158-168; Ellis, Steven G., 1981. „Henry VIII, rebellion”, p. 525.

34 Ellis, Steven G.; Maginn, Christopher, 2007. The Making of the British Isles, The State of Britain and Ireland, 1450-1660, London-New York, p. 100.

35 Ellis Steven G., 1980. „Thomas Cromwell and Ireland, pp. 516-517; Ellis, Steven G., 1981. „Henry VIII, rebellion”, p. 523; Magin, Christopher, 2012. Wiliam Cecil, Ireland, and the Tudor state, Oxford, p. 43.

36 Woodward, Geoff, 2008. Rebellion and the Disorder under Tudors 1485-1603, London, p. 55. 
English. Therefore, for the authors of the Annals, the rebellion of Silken Thomas, a descendant of Normans, was probably too distant geographically to devote more time to the pages of their work. This is understandable because the Irish in the Middle Ages and early modern period identified primarily with their clan or region. Also, the military activities carried out by the Fitzgeralds family from the 12th century until the Silken Thomas rebellion were often aimed at the region of origin of both the authors and the main sponsor of the Annals, which maybe had to have some impact on the relationship of the source studied by us.

From a military historian's point of view, we can present the information contained in that source in the following way about the Kildare rebellion:

- the outbreak of rebellion, without providing data on the numbers of Silken Thomas and the English

- attack on Dublin, murders of representatives of the government and church associated with the Tudors

- control and armed plunder of Pale by Thomas and his allies

- The arrival of William Skeffington and Leonard Gray, with a great fleet, without specifying the numbers of troops they brought to Ireland

- The action of the two aimed at plundering the lands of Kildare and his supporters

- the capture of Maynooth Castle by the English

- the guerrilla war waged by Thomas against the English, with the support of the Irish from the south of the island, especially the O'Briens and O'Connors families.

- betrayal of Thomas uncles, followed by his capture and sending to England, by Leonard Gray

- the capture of his uncles and the subsequent execution of all representatives of the FitzGeralds family in the Tower

The laconic nature of Annales' accounts, as well as the omission by this source of many important data, which I mentioned earlier in the article, makes it an auxiliary material related to military history in the case of the Kildare rebellion. This is interesting because, in the context of later revolts that broke out in Ireland against the authority of the Tudors or Stuarts, in the era of further conquest of the island, this source is a very valuable research material in this field.

\section{References}

A New History of Ireland, Vol. 3: Early Modern Ireland, 1534-1691, ed. T.W. Moody, F.X. Martin, Oxford 1991.

Brady, Ciaran, 2002. The Chief Governors: The Rise and Fall of Reform Government in Tudor Ireland 1536-1588, Cambridge.

Bradshaw, B., 1977. 'Cromwellian reform and the origins of the Kildare rebellion', Transactions of the Royal Historical Society, 5th series, 27, pp. 69-93.

Connellan, Owen, 1846. The Annals of Ireland, translated from the original Irish of the Four Masters, Dublin.

Concannon, Helena, 1948. John O’Donovan and “The Annals of the Four Masters”, Studies: An Irish Quarterly Review Vol. 37, No. 147, pp. 300-307.

Cunningham, Bernadette; Gillespie, Raymond, 1990. „Englishmen in sixteenth-century Irish Annals”, Irish Economic and Social History, Vol. 17, pp. 5-21.

Cunningham, Bernadette, 2010. The Annals of the Four Masters: Irish History, Kingship, and Society in the Early Seventeenth Century, Dublin.

Ellis Steven G., 1976-77. 'Tudor policy and the Kildare ascendancy in the lordship of Ireland', Irish Historical Studies 20 (1976-7), pp. 235-71.

Ellis Steven G., 1980. „Thomas Cromwell and Ireland, 1532-1540”, The Historical Journal, Vol. 23, No. 3, pp. 497-519.

Ellis, Steven G., 1981. „Henry VIII, rebellion and the rule of law”, The Historical Journal, 24, 513-531.

Ellis, Steven G.; Maginn, Christopher, 2007. The Making of the British Isles, The State of Britain and Ireland, 1450-1660, London-New York.

Guy, John, 2000. The Tudors: A very short introduction, Oxford.

O'Donovan, John, ed., 1856. Annala rioghachta Eireann: Annals of the Kingdom of Ireland, by the Four Masters, from the earliest period to the year 1616 (in Irish and English) (2nd ed.), Volume 5 (AD 1501-1588), Royal Irish Academy.

Hamilton, Hans Claude, ed., 1860. Calendar of the State Papers relating to Ireland of the reign Henry VIII., Edward VI., Mary and Elisabeth, London.

Lizeray, Henri, 1882. Le livre des quatre maîtres: Annales du royaume d'Irlande, depuis les origines jusqu'à l'arrivée de saint Patrice, Leroux. 
Lydon, James, 1995. „Ireland and the English Crown, 1171-1541”, Irish Historical Studies, Vol. 29, No. 115, pp. 281-294.

Magin, Christopher, 2012. Wiliam Cecil, Ireland, and the Tudor state, Oxford.

Marquis of Kildare (Charles William FitzGerald, 4th Duke of Leinster), The Earls of Kildare and their ancestors from 1057 to 1773, Dublin 1858.

Maxwell, Constantia, 1979. The Rebellion of "Silken Thomas" (1534-5), Dublin Historical Record

Vol. 32, No. 2, p. 68 (1 page).

McCormack, Anthony M., 1997. „Internecine Warfare and the Decline of the House of Desmond, c. 1510 - c. 1541”, Irish Historical Studies, Vol. 30, No. 120, pp. 497-512.

McCorristine, Laurence 1987. The revolt of Silken Thomas, Dublin.

Murray, James, 2008. Enforcing the English Reformation in Ireland: Clerical Resistance and Political Conflict in the Diocese of Dublin, 1534-1590, Cambridge.

Mc Carthy, Daniel, 2008. The Irish Annals: Their Genesis, Evolution and History, Dublin.

Quinn, David B., 1961., „Henry VIII and Ireland, 1509-34”, Irish Historical Studies, Vol. 12, No. 48, pp. 318-344.

Ó Muraíle, Nollaig, 1987. “The autograph manuscripts of the Annals of the Four Masters”, Celtica, vol. 19, pp. 75-95.

Ó. Siochrú, Micheál, 1996. „Foreign Involvement in the Revolt of Silken Thomas, 1534-5”, Proceedings of the Royal Irish Academy. Section C: Archaeology, Celtic Studies, History, Linguistics, Literature, Vol. 96C, No. 2, pp. 49-66.

O'Sullivan, William, 1999. "The Slane manuscript of the Annals of the Four Masters”, Ríocht na Mídhe: Journal of the County Meath Historical Society, vol. 10, pp. 78-85.

R. Edwards, Dudley, 1934, „Venerable John Travers and the Rebellion of Silken Thomas”, Studies: An Irish Quarterly Review Vol. 23, No. 92, pp. 687-699.

Woodward, Geoff, 2008. Rebellion and the Disorder under Tudors 1485-1603, London. 